\title{
Penambahan Ampas Sagu Fermentasi (Metroxylon sago) Terhadap Performa Ayam Kampung Super Fase Starter
}

\author{
Addition of Fermented Sago Dregs (Metroxylon sago rotb) to Super Kampung \\ Chicken Performance in the starter phase
}

\author{
Ahmad Sudarto, *Suparmin Fathan, dan Fahria Datau \\ Jurusan Peternakan, Fakultas Pertanian, Universitas negeri Gorontalo \\ *Corresponding Auhor: email: suparmin.fathan@ung.ac.id
}

\begin{abstract}
This study aims to determine the performance of super native chickens fed with fermented sago dregs as a substitute for corn in the ration. Super native chickens used in the study were 80 chickens. The research design used a completely randomized design (CRD) with 4 treatments and 4 replications. The treatment in this study was P0 (without a mixture of fermented sago dregs), P1 (rations with an additional 10\% fermented sago dregs), P2 (rations with an additional 20\% fermented sago dregs), P3 (rations with an additional 30\% fermented sago dregs). The variables observed were ration consumption, body weight gain, and ration conversion. Based on the analysis of variance, it showed that dietary consumption was not significantly different $(P>0,05)$, while body weight gain and diet conversion were significantly differed $(\mathrm{P}<0,01)$. Therefore, the use of fermented sago dregs in the ration of Super Kampung chickens can significantly affect body weight gain and ration conversion up to the level of $20 \%$.
\end{abstract}

Keywords; Performance; Super Free-range Chicken; Sago Waste; Fermentation.

\begin{abstract}
ABSTRAK
Penelitian ini bertujuan untuk mengetahui perfoma ayam kampung super yang diberi ampas sagu fermentasi sebagai bahan pakan pengganti jagung dalam ransum. Ayam kampung super yang digunakan dalam penelitian adalah sebanyak 80 ekor. Rancangan penelitian menggunakan Rancangan Acak Lengkap (RAL) dengan 4 perlakuan dan 4 ulangan. Perlakuan pada penelitian ini adalah P0 (tanpa campuran ampas sagu fermentasi), P1 (Ransum dengan tambahan 10\% ampas sagu fermentasi), P2 (Ransum dengan tambahan 20\% ampas sagu fermentasi), P3 (Ransum dengan tambahan 30\% ampas sagu fermentasi). Variabel yang diamati adalah konsumsi ransum, pertambahan bobot badan dan konversi ransum. Berdasarkan analisis sidik ragam menunjukkan bahwa konsumsi ransum tidak berbeda nyata $(\mathrm{P}>0,05)$, sedangkan pertambahan bobot badan dan konversi ransum sangat berbeda nyata $(\mathrm{P}<0,01)$. Oleh karena itu, penggunaan ampas sagu fermentasi dalam ransum ayam kampung super dapat berpengaruh nyata terhadap pertambahan bobot badan dan konversi ransum sampai pada level $20 \%$.
\end{abstract}

Kata kunci; Perfoma, Ayam Kampung Super, Ampas Sagu, Fermentasi.

Cara Mengutip (APA Citation Style):

Sudarto, A., Fathan, S., dan Datau, F., 2021. Penambahan Ampas Sagu Terfermentasi (Metroxylon sago)dalam Ransum Terhadap Performa Ayam Kampung Super Fase Starter. Jambura Journal of Animal Science, 3(2), 96-104 


\section{PENDAHULUAN}

Usaha ternak ayam kampung super banyak dijalankan oleh peternak di Daerah Gorontalo dalam bentuk mitra atau pun perorangan. Ayam kampung super masih mempunyai kesamaan dengan ayam kampung biasa tetapi pertumbuhan ayam kampung super lebih cepat dibanding dengan ayam kampung biasa sehingga untuk mendapatkan keuntungan lebih cepat.

Menurut (Sigaha, dkk, 2019; Dunggio, dkk, 2021) menyatakan bahwa, ayam kampung super di umur 2 bulan dengan bobot potong saat panen 814,6850,75 gram/ekor, sedangkan diumur 12 minggu bobot akhir 1242,2 gram (Jacob, C. C., dkk, 2019), dan pertumbuhan yang cepat., karena ayam ini memiliki $1 / 2$ gen dominan yang berasal dari ayam leghorn betina (Masili, dkk, 2018; Dako, dkk 2019)., dan merupakan keturunan ayam kampung, yakni mewarisi $1 / 2$ genetic dari sifat ayam kampung (Dako et al, 2020; Saleh, dkk. (2020).), sehingga dapat memanfaatkan pakan lokal dalam pertumbuhannya. Untuk meningkatkan produktivitas dari ternak ayam dapat juga dilakukan dengan pengaturan lingkungan, terutama pakan yang berkualitas, karena sekitar $2 / 3$ dari biaya produksi adalah pakan.

Biaya pakan yang tinggi karena sebagian besar dari bahan pakan tersebut adalah bahan impor seperti jagung dan kosentrat. Untuk menanggulangi masalah tersebut diperlukan pakan alternatif yang penggunaanya tidak bersaing dengan kebutuhan manusia, masih memiliki kandungan gizi, mudah didapat, harga relatif murah dan aman dikonsumsi oleh ternak.

Tanaman sagu merupakan tanaman tropis yang menyebar di dataran rendah Asia Tenggara dan Malanesia., dan Indonesia merupakan produsen sagu yang terbesar di dunia, karena lebih dari $85 \%$ total area sagu dunia berada di Indonesia. Tanaman sagu memiliki potensi karbohidrat yang tinggi, produktivitas yang tinggi, dan dapat dijadikan berbagai macam produk turunan. Pengolahan sagu dijumpai limbah hasil ikutan yang berupa kulit, batang, dan ampas. Limbah ini dapat dijadikan pakan untuk ternak.

Limbah ampas sagu masih sangat jarang digunakan untuk kebutuhan ternak. Alternatif penggunaan ampas sagu sebagai bahan ransum ternak merupakan hal yang positif walaupun disadari bahwa penggunaannya sebagai pakan ternak belum optimal karena mempunyai kendala pada tingginya kadar serat kasar 4.99\% dan rendahnya kadar protein $1.79 \%$, untuk menurunkan kadar serat kasar yang tinggi didalam ampas sagu perlu dilakukannya fermentasi. Pengunann ampas sagu untuk ternak ruminansia dapat bisa digunakan secara langsung atau diolah dalam bentuk wafer (Adelina, T.,dkk, 2020), namun jika diberikan pada ternak unggas tidak dapat diberikan secara langsung, dibutuhkan proses fermentasi (Suebu, \& Tanjung, 2020)., karena menurut Saleh, dkk (2019) fermentasi mampu memperbaiki nilai nutrisi dari limbah yang memiliki serat tinggi menjadi lebih rendah. Bahan pakan alternatif untuk ternak yang berasal dari ampas sagu masih terbatas penggunaanya, khususnya sebagai bahan penyusunan ransum ternak karena adanya serat kasar yang tinggi dan nilai protein yang rendah (Rianza, 2019), sehingga perlu ditingkatkan kualitas melalui fermentasi.

Penggunan MA-11 sebagai starter untuk fermentasi pada ampas sagu ini belum banyak dilakukan, oleh karena itu perlu adanya penelitian untuk mengetahui pengaruh dari penambahan kosentrasi MA-11. Menurut Artarizki (2013) microbacter alfaafa (MA-11) adalah sumer dekomposer mikroba yang mampu merombak rantai organik dengan cepat serta mengembalikan kesehatan dan kegemburan tanah. Penambahan 4\%-12\% ampas sagu fermentasi (FAS) dalam ransum meningkatkan bobot ayam kampung hingga mencapai 17,8\%,. (Suebu, \& Tanjung, (2020) Tujuan penelitian ini 
adalah untuk mengetahui perfoma ayam kampung super yang diberi ampas sagu fermentasi sebagai bahan tambahan dalam ransum

\section{METODE PENELITIAN}

Penelitian ini telah dilakukan pada bulan Agustus-November 2020. di Desa Huluduotamo Kecamatan Suwawa Kabupaten Bonebolango Provinsi Gorontalo. Alat-alat yang digunakan: kandang bateray yang berukuran panjang $70 \mathrm{~cm} \times$ tinggi $60 \mathrm{~cm} \times$ lebar $70 \mathrm{~cm}$ sebanyak 16 unit; dilengkapi dengan perlengkapan kandang, 1 buah timbangan digital (Kitchen scale) dengan kepekaan 0,01 gram. Bahan penelitian terdiri dari: ayam kampung super (180 ekor) berumur dua minggu, bahan penyusun ransum yaitu jagung giling, dedak halus, kosentrat (BR 1), ampas sagu, top mix dan MA-11 (Microbacter alaafa). Kebutuhan nutrisi ayam kampung super disajikan pada Tabel 1

Tabel 1. Kebutuhan nutrisi ayam kampung super (Gallus domesticus)

\begin{tabular}{lcc}
\hline \multirow{2}{*}{ Kebutuhan nutrisi } & \multicolumn{2}{c}{ Umur (hari) } \\
\cline { 2 - 3 } & $0-28$ & 28-panen \\
\hline Energi Metabolisme (kkal/kg) & 3100 & 2900 \\
Protein (\%) & $20-24$ & $15-19$ \\
Lemak Kasar (\%) & $4-7$ & $4-7$ \\
Serat Kasar (\%) & $5-6$ & $5-6$ \\
Kalsium (\%) & $1-1,20$ & $1-1,20$ \\
Fosfor (\%) & 0,40 & 0,35 \\
Lisin (\%) & 0,85 & 0,60 \\
\hline
\end{tabular}

Sumber: Kaleka, 2015

Tabel 2. Komposisi ransum penelitian.

\begin{tabular}{llccc}
\hline BahanPakan (\%) & P0 & P1 & P2 & P3 \\
\hline JagungKuning & 47 & 39 & 30 & 24 \\
Ampas sagu fermentasi & 0 & 10 & 20 & 30 \\
Konsentrat & 31 & 32 & 33 & 34 \\
Dedak Halus & 20 & 17 & 15 & 10 \\
Premix (Top mix) & 2 & 2 & 2 & 2 \\
\hline Total & 100 & 100 & 100 & 100 \\
\hline
\end{tabular}

Keterangan: ${ }^{*}$ Komposisi Top Mix Produksi Medion. No regisiter Kementan RI. : D 1207151 FTS.3).

Tabel 3. Komposisi nutrisi bahan pakan pada penelitian

\begin{tabular}{lllll}
\hline Kandungan Nutrisi & P0 & P1 & P2 & P3 \\
\hline ME (Kkal/kg) & 2950.442 & 2935.357 & 2909.965 & 2915.494 \\
Protein Kasar $(\%)$ & 18.42 & 18.049 & 17.675 & 17.31 \\
Serat Kasar $\%$ ) & 6.568 & 7.154 & 7.797 & 8.269 \\
LemakKasar (\%) & 5.013 & 5.909 & 6.838 & 7.668 \\
Ca (\%) & 3.321 & 3.008 & 2.655 & 2.422 \\
P (\%) & 1.2844 & 1.1668 & 1.056 & 0.9248
\end{tabular}

Tabel 4. Hasil uji laboratorium Komposisi Kandungan Ampas Sagu sebelum dan sesudah fermentasi menggunakan MA-11 Microbacter Alfaafa.

\begin{tabular}{lcc}
\hline \multicolumn{1}{c}{ Zat Gizi } & $\begin{array}{c}\text { Ampas Sagu (tanpa } \\
\text { fermentasi) }\end{array}$ & $\begin{array}{c}\text { Ampas Sagu (sesudah } \\
\text { fermantasi) }\end{array}$ \\
\hline Protein kasar (\%) & 1.79 & 1,47 \\
Serat kasar (\%) & 4.99 & 4,11 \\
Gross Energy (Kkal/kg) & 4215 & 3470.33 \\
\hline Sumber: Sudarto, 2020. (Hasil uji Lab. Jurusan Nutrisi dan Makanan Ternak Fapet Unhas, 2020)
\end{tabular}




\section{Pembuatan Ampas Sagu Fermentasi (FAS)}

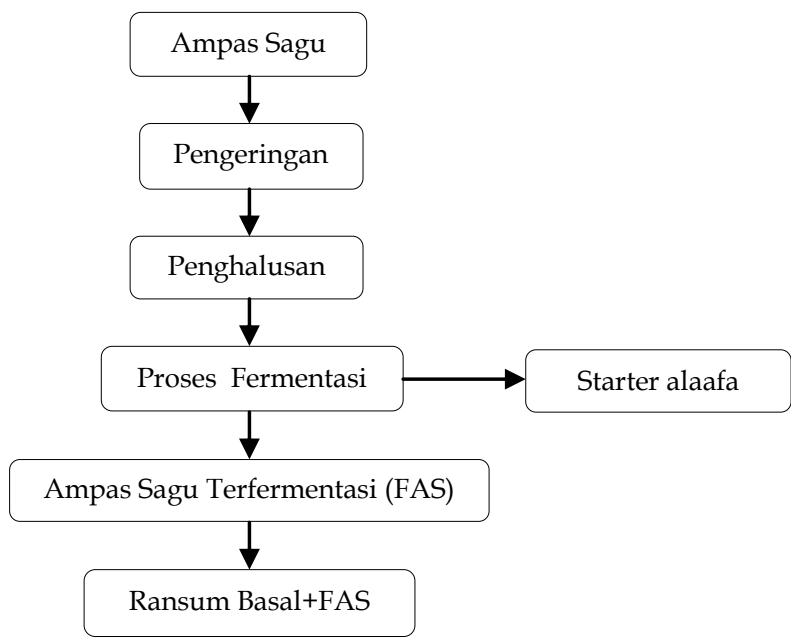

Gambar 1 Proses Pembuatan Ampas Sagu Terfermentasi

Ampas sagu yang diperoleh langsung dari pabrik pengolahan pati sagu kemudian dijemur dibawah sinar matahari sampai benar-benar kering, selanjutnya ampas sagu yang sudah melalui proses penjemuran kemudian digiling halus, setelah digiling halus ampas sagu difermentasi menggunakan 80 cc molases dan 40 cc MA-11 (microbacter alfaafa), lalu dimasukan kedalam drum tong ditutup rapat dalam keadaan anaerob selama 5 hari. Ampas sagu yang sudah difermentasi selama 5 hari kemudian ditambahkan dengan ransum ayam kampung super sesuai dengan perlakuan dalam penelitian. Penilaian perfoma ayam kampung super dilakukan pada: Konsumsi ransum pertambahan bobot badan, dan konversi ransum

Pertambahan bobot badan ayam kampung super dihitung mengikuti saran Lauma, (2018); Labado, (2018); Dunggio, dkk, (2021)

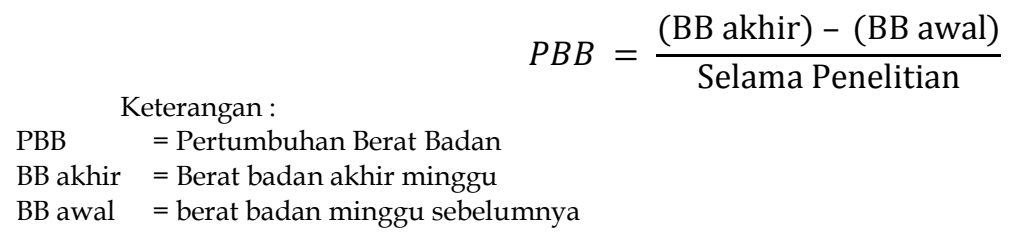

Penelitian ini merupakan penelitian experiment, menggunakan Rancangan Acak Lengkap (RAL) yang terdiri dari 4 perlakuan dan 4 ulangan, setiap ulangan ditempati 5 ekor ayam, sehingga total ayam kampung super yang digunakan sebanyak 80 ekor. Perlakuan yang digunakan dalam penelitian terdiri dari:

P0 $=$ Ransum Ayam Kampung Super tanpa ampas sagu fermentasi

P1 $=$ Ransum Ayam Kampung Super dengan tambahan $10 \%$ ampas sagu fermentasi 
P2 $=$ Ransum Ayam Kampung Super dengan tambahan $20 \%$ ampas sagu fermentasi

P3 $=$ Ransum Ayam Kampung Super dengan tambahan $30 \%$ ampas sagu fermentasi
Model penelitian menggunakan rancangan acak lengkap (RAL) menurut petunjuk (Steel dan Torrie. 1993) adalah sebagai berikut:

Keterangan :

$Y i j=\mu+t i+e i j$

$Y_{i j}=$ Hasil pengamatan dari perubah perlakuan ke-i dengan ulangan ke-j

$\mu=$ Nilai tengah umum

$t i=$ pengaruh perlakuan $k e-i$

eij = pengaruh galat percobaan dari perlakuan ke-I dan ulangan ke-j

$i=$ Jumlah perlakuan 1,2,3,4

$j=$ jumlah ulangan pada perlakuan ke-1,2,3

Analisa Data

Data dianalisa menggunakan Analisis Sidik Ragam (ANSIRA). Bila terdapat perbedaan nyata maka dilanjutkan dengan uji lanjut Duncan.

HASIL DAN PEMBAHASAN

Konsumsi Ransum Ayam Kampung Super Fase Stater

Konsumsi ransum adalah jumlah makanan yang dikonsumsi oleh ternak untuk mencukupi hidup pokok dan produksi hewan tersebut (Fahrudin, dkk 2016). Berdasarkan analisis statistika menggunakan analisis sidik ragam (ANSIRA), penggunaan ampas sagu fermentasi menggunakan MA-11 dalam ransum ayam kampung super, tidak memberikan pengaruh yang signifikan terhadap konsumsi ransum ayam $(\mathrm{P}>0,05)$. Nilai rata-rata konsumsi pakan ayam kampung super yang diberi ransum mengandung ampas sagu fermentasi selama penelitian dapat dilihat pada gambar 1.

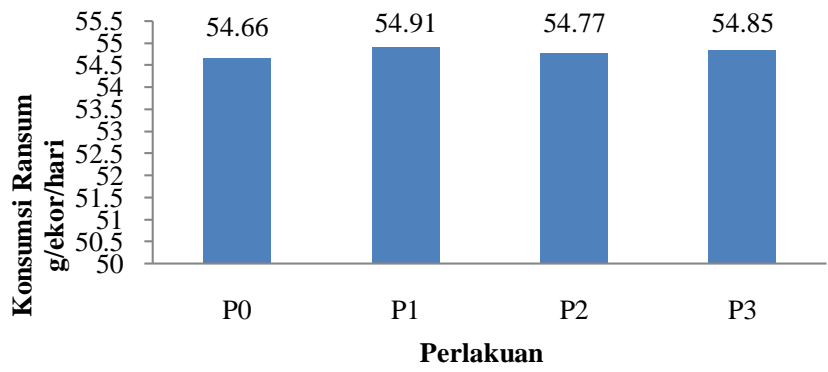

Gambar 1. Rataan konsumsi ransum ayam kampung super setiap perlakuan.

Berdasarkan rataan pada gambar 1. Jumlah Konsumsi ransum ayam kampung super yang diberi pakan mengandung ampas sagu fermentasi selama penelitian secara rataan berturut-turut adalah $\mathrm{P} 0$ (54,66 g/ekor/hari); P1 (54,91 g/ekor/hari); P2 (54,77 g/ekor/hari); P3 (54,85 g/ekor/hari). Dari hasil analisis tersebut menggambarkan penggunaan ampas sagu fermentasi dengan MA-11 dalam ransum ayam kampung super sampai dengan taraf $30 \%$ berpengaruh tidak nyata terhadap pertambahan bobot badan ayam kampung super di fase starter, konsumsi yang sama ini di akibakkan nilai protein dan energy dalam ransum adalah sama, dan juga ampas sagu fermentasi setelah dicampurkan denga pakan basal tidak berbau dan mempengaruhi warna dari ransum basal, sehingga ayam mengkonsumsi secara normal.

Menurut Nuraini, dkk (2012) konsumsi pakan dipengaruhi oleh beberapa faktor antara lain: umur, 
palatabilitas ransum, kesehatan ternak, jenis ternak, aktivitas ternak, energi ransum, tingkat produksi, kuantitas dan kualitas ransum. Wahyu (2004) menyatakan bahwa, konsumsi ransum dipengaruhi oleh zat zat makanan yang terkandung dalam ransum.

\section{Pertambahan Bobot Badan Ayam Kampung Super Fase Stater}

Pertambahan bobot badan didefinisikan sebagai pertambahan dalam bentuk dan berat jaringan seperti otot, tulang, jantung dan semua jaringan tubuh yang lain. Hasil penelitian pemggunaan ampas sagu termentasi terhadap pertambahan bobot badan ayam kampung super dapat dilihat pada gambar 2 .

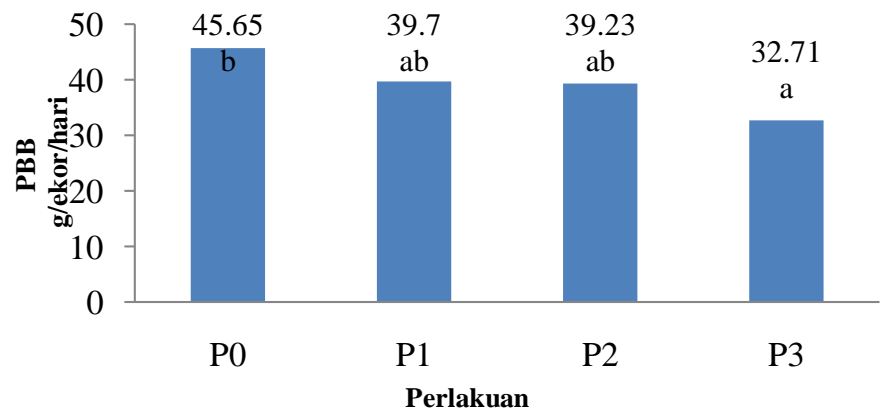

Gambar 1. Rataan pertambahan bobot badan ayam kampung super setiap perlakuan

Pertambahan bobot badan ayam kampung super hasil penelitian yang diberi ransum mengandung ampas sagu fermentasi dengan MA-11 secara rataan per ekor/hari berturut-turut adalah P3 $(32,71) ;$ P2 $(39,23) ;$ P1 $(39,7) ;$ P0 $(45,65)$. Berdasarkan analisis sidik ragam (ANSIRA), penggunaan ampas sagu yang difermentasi dengan MA-11 dalam ransum ayam kampung super memberikan pengaruh yang signifikan terhadap pertambahan bobot badan ayam kampung super selama penelitian $(\mathrm{P}<0,01)$. Dari uji lanjut tersebut dihasilkan bahwa perbedaan yang signifikan terdapat pada P0 (kontrol) yang berbeda nyata dengan P3 (Ransum ayam kampung super dengan tambahan 30\% ampas sagu fermentasi), dari hasil uji statistika tersebut membuktikan bahwa pertambahan bobot badan ayam kampung super hasil penelitian tertinggi ada pada P0 (kontrol) dan terendah ada pada P3, hal ini disebabkan penggunaan ampas sagu fermentasi sampai taraf $30 \%$ mempengaruhi bobot badan ayam. Semakin tinggi konsentrasi ampas sagu fermentasi dalam ransum, maka akan menyebabkan penurunan pertambahan bobot badan sehingga pakan sulit dicerna oleh ternak, Penurunan bobot badan terjadi secara signifikan pada perlakuan P3, Hal ini disebabkan oleh kandungan serat kasar dalam ampas sagu fermentasi sebesar $4.11 \%$, serat kasar yang tinggi berakibat perjalanan makan dalam saluran pencernaan sangat lambat dan sulit dicerna., karena unggas mempunyai keterbatasan mencerna serat kasar karena organ fermentor terletak pada bagian akhir dari organ absorpsi.,Hal ini di dukung pendapat Rianza (2019) menyatakan bahwa, pertambahan bobot badan dipengaruhi oleh kualitas dan kuantitas pakan yang di konsumsi oleh ternak, sehingga perbedaan kandungan zat-zat pada pakan dan banyaknya pakan yang di konsumsi akan berpengaruh pada pertambahan bobot badan pada ternak. Ditambahkan Made et al. (2017) menyatakan bahwa, faktor utama yang mempengaruhi pertambahan bobot badan adalah jumlah konsumsi ransum ayam serta kandungan energi dan protein yang terdapat dalam ransum karena energi dan protein sangat penting dalam 
mempengaruhi kecepatan pertambahan bobot badan.

Menurut Ichwan

menyatakan bahwa, secara umum penambahan bobot badan akan dipengaruhi oleh jumlah konsumsi pakan yang di makan dan kandungan nutrisi yang terdapat dalam pakan tersebut. Kadar serat kasar yang terdapat didalam ransum unggas yang baik (Rasional) sebaiknya tidak boleh melampaui $4 \%$ fase stater dan untuk fase finisher $4,5 \%$ (Nurdiyanto, dkk, 2015).

Konversi Ransum Ayam Kampung Super Fase Stater

Konversi pakan adalah perbandingan antara jumlah komsumsi pakan dan pertambahan bobot badan dalam satuan waktu tertentu. Hasil analisis sidik ragam konversi ransum dapat dilihat pada Gambar 3.

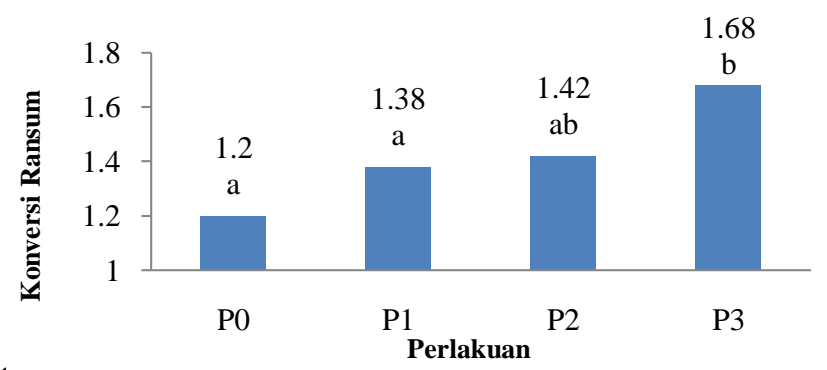

Gambar 3. Gratık Kataan konversı ransum ayam kampung super setıap perlakuan.

Nilai konversi ransum ayam kampung super yang diberi pakan yang mengandung ampas sagu yang terfermentasi dengan MA-11 secara rataan berturut-turut adalah P0 (1,2); P1 (1,38); P2 $(1,42)$; P3 $(1,68)$. Hasil analisis statistika menunjukan penggunaan ampas sagu fermentasi memberikan pengaruh yang signifikan terhadap konversi pakan ayam kampung super $(\mathrm{P}<0,05)$, Perbedaan konversi ransum dalam penelitian ini menunjukan peningkatan nilai konversi ransum seiring dengan bertambahnya level konsentrasi ampas sagu dalam ransum, artinya semakin tinggi level penggunaan ampas segu fermentasi dalam ransum maka semakin rendah pakan yang terabsorbsi dalam tubuh ternak untuk menjadi daging dan hanya terbuang menjadi feses. Hal ini sejalan dengan Mulyono (2004) menyatakan bahwa, konversi ransum yang tinggi menunjukkan penggunaan ransum yang kurang efisien, dan sebaliknya angka yang mendekati 1 berarti semakin efisien. Allama, dkk (2012) menyatakan bahwa, nilai konversi ransum yang rendah menunjukkan bahwa efesiensi penggunaan ransum yang baik, karena semakin efesien ayam mengonsumsi ransum untuk memproduksi daging. Tingginya nilai konversi ransum pada ayam yang mendapatkan pakan dengan tambahan ampas sagu diduga karena kandungan serat kasar dalam ampas sagu yang masih tinggi, sehingga ransum perlakuan sulit dicerna oleh ternak karena sifat biologis ayam yang system pencernaannya yang sulit mecerna serat kasar karena organ fermentor terletak diakhir saluran pencernaan ayam. Hal ini sesuai pendapat Wahju (2004) unggas tidak memiliki enzim selulase yang dapat memecah komponen serat kasar berupa selulosa.

\section{KESIMPULAN}

Penambahan ampas sagu yang terfermentasi didalam ransum ayam kampung super hingga 30\% menurunkan pertambahan bobot badan dan meningkatkan konversi ransum. Penggunaan ampas sagu terfermentasi paling baik digunakan didalam pakan ayam kampung super sampai pada taraf $20 \%$. 
DAFTAR PUSTAKA

Allama, H., Sofyan, O., Widodo, E., \& Prayogi, H.S. (2012). Pengaruh penggunaan tepung ulat kandang (Alphitobius diaperinus) dalam pakan terhadap penampilan produksi ayam pedaging. Jurnal Ilmu-Ilmu Peternakan, 22(3), 1-8.

Adelina, T., Mucra, D. A., Harahap, A. E., \& Syarbini, M. (2020). Pengaruh Pemberian Wafer Ransum Komplit Yang Ditambahkan Ampas Sagu (Metroxylon Sp) Terhadap Penampilan Produksi Sapi Bali. Jambura Journal of Animal Science, $3(1), 16-25$.

Artarizki, A. T. (2012). MA-11, Kolaborasi Mikroba Super. Dilihat 22 April 2013.http://homeschoolingkaksetos emarang.com/article/99275/ma-11kolaborasi-mikroba-super.html.

Dako, S., Ilham, F., Laya, N. K., \& Yusuf, F. M. (2020). Nheritance of external genetic characteristics in chicken through triple crossing model. International Journal of Advanced Science and Technology, 29(9 Special Issue).

http://sersc.org/journals/index.ph $\mathrm{p} / \mathrm{IJAST} /$ article/view/13134

Dako, S., Ilham, F., Laya, N. K., \& Yusuf, M. F. (2019). Manajemen pembibitan Ternak. Buku Ajar, Publisher Arthasamudra ISBN, 978-623.

Dako, S. (2019). Crossbreding Between Native Chiken And Leghorn Chiken Strain Isa Brown. Jurnal Peternakan, 16(1), 1-9.

Dunggio, A., Datau, F., Dako, S., dan Handayani, S. (2021) Evaluasi Karkas Ayam Kampung Super Yang Diberi Tepung Kunyit (Curcuma domestica val) Jurnal AgriSains, 22 (1), 11-16

Publisher: Animal husbandry department, Gorontalo State University http://ejurnal.ung.ac.id/index.php/jjas/issue/archive
Ellen j. Saleh, Suyadi, Irfan junaidi and Eko widodo. (2019); Nutritive Evaluation Of Corn Straw Fermented By Trichoderma Viride As Cross Breed Chicken Feed Stuff In Gorontalo Regency. Int. J. Of Adv. Res.7 (Oct). 660-666] (Issn 2320-5407). www.journalijar.com

Fahrudin, A., Tanwirah, W., \& Indrijani, H. (2016). Konsumsi Ransum, Pertambahan Bobot Badan dan Konversi Ransum Ayam Lokal di Jimmy's Farm Cipanas Kabupaten Cianjur. Fapet Unpad.

Ichwan, (2003). Membuat Pakan Ras Pedaging. Agro Media Pustaka. Tanggerang.

Jacob, C. C., Leke, J. R., Sarajar, C. L., \& Tangkau, L. M. (2019). Penampilan Produksi Ayam Kampung Super Melalui Penambahan Juice Daun Gedi (Abelmochus Manihot L. Medik) Dalam Air Minum. ZOOTEC, 39(2), 362-370.

Lauma, A. P. (2018). Pertumbuhan Ayam $\mathrm{Kb}$ (Kampung Broiler) Fase Starter. Skripsi, 1(621413075). ttps://repository.ung.ac.id/skripsi/ show/621413075/pertumbuhanayam-kb-kampung-broilerfasestarter.html

Labado, M. (2018). Bobot Badan Dan Konsumsi Ransum Ayam Hasil Persilangan Ayam Kampung Dan Ayam Ras Petelur Strain Isa Brown Pada Fase Starter. Skripsi, 1(621413086). https:// repository.ung.ac.id/skripsi /show/621413086/bobot-badandan-konsumsi-ransum-ayam-hasilpersilangan-ayam-kampung-danayam-ras-petelur-strain-isa-brownpada-fase-starter.html 
Made, L. S., S. Tantalo., dan K. Nova. 2017. Performa Ayam KUB (Kampung Unggul Balitnak) Periode Grower Pada Pemberian Ransum dengan Kadar protein Kasar yang Berbeda. Jurnal. Fakultas Pertanian. Universitas Lampung. Vol 1(3): 3641.

Masili, S., Dako, S., Ilham, F., \& Gubali, I. S. (2018). Heritabilitas Bobot Telur, Bobot Tetas Dan Bobot Badan Ayam Hasil Persilangan Umur 1 Minggu (DOC). Jambura Journal of Animal Science, 1(1), 1-5.

Mulyono, S. (2004). Beternak Ayam Buras Berorientasi Agribisnis. Penebar Swadaya. Jakarta

Nuraini, Sabrina dan Latif S., A. (2012). Fermented product by Monacus purpureus in poultry diet effects on laying performance and egg quality. Pakistan Journal of Nutrition 11: 507-510

Nurdiyanto, R., Sutrisna, R., \& Nova, K. (2015). Pengaruh Ransum dengan Presentase Serat Kasar yang Berbeda Terhadap Perfoma Ayam Jantan Tipe Medium Umur 3-8 Minggu. Jurusan Peternakan Fakultas Pertanian Universitas Lampung. Lampung

Novarianto H., Tulalo MA., Kumaunang J., Manaroinsong E., Sulistyowati E. 2016. Seleksi dan Pelepasan Varietas Selat Paanjang Meranti untuk Pengembangan Sagu. J. Metroxylon Indonesia. 1(1): 1-9
Rianza, R. (2019). Perdoman Itik Pedaging yang Diberi Ampas Sagu Sebagai Pengganti Dedak Halus. Prossiding. Fakultas Peternakan UIN SUSKA. Riau

Safriyanto Dako, Fahrul Ilham, Nibras. K. Laya, Frida. M Yusuf. (2020). NHERITANCE OF EXTERNAL GENETIC CHARACTERISTICS IN CHICKEN THROUGH TRIPLE CROSSING MODEL. International Journal of Advanced Science and Technology, 29(9s), 549-558. Retrieved from

http:/ / sersc.org/journals/index.php /IJAST/article/view/13134

Saleh, U. (2020). Keseimbangan Genetik Eksternal pada Ayam Hasil Silangan. Jambura Journal of Animal Science, 2(2), 76-89

Suebu, Y., \& Tanjung, R. H. (2020). Fermentasi Ampas Sagu (FAS) sebagai Pakan Alternatif Untuk Meningkatan Pertumbuhan Bobot Ayam Kampung. Buletin Anatomi dan Fisiologi (Bulletin of Anatomy and Physiology), 5(1), 1-7.

Sigaha, F., Saleh, E. J., \& Zainudin, S. (2019). Evaluasi Persentase Karkas Ayam Kampung Super Dengan Pemberian Jerami Jagung Fermentasi. Jambura Journal of Animal Science, 2(1), 1-7.

Stell, R. D. G.dan J. H. Torrie., 1993. Prinsip dan Prosedur Statistika (Pendekatan Biometrik) Penerjemah B. Sumantri. Jakarta.

Wahju. 2004. Ilmu Nutrisi Unggas. Yogyakarta: Universitas Gajah Mada Press 